\title{
The effect of jengkol (Archidendron pauciflorum) fruit peel ethanolic extract to heart histologic of rat induced by streptozotocin
}

\author{
SELMA ALAMANDA ABADI", ZULFA ILLIYYIN, JASMINE RAISSA RACHMADINA, \\ DESAK MADE MALINI ${ }^{* \vee}$ \\ Department of Biology, Faculty of Mathemathics and Natural Sciences, Universitas Padjadjaran. Jl. Raya Bandung Sumedang km.21, Jatinangor, \\ Sumedang 45363, West Java, Indonesia. Tel.: +62-228-4288828, "email: alamandaselma@ gmail.com, vv desak_malini@yahoo.com
}

Manuscript received: 3 July 2018. Revision accepted: 20 August 2018.

\begin{abstract}
Abadi SA, Illiyyin Z, Rachmadina JR, Malini DM. 2018. The effect of jengkol (Archidendron pauciflorum) fruit peel ethanolic extract to heart histologic of rat induced by streptozotocin. Biofarmasi J Nat Prod Biochem 16: 59-63. Indonesia is ranked 7th out of 10 countries with the highest number of diabetic patients globally. Diabetes mellitus is a disease that can cause heart disorders, and adults who suffer from DM are four times more likely to develop heart disease. Jengkol fruit peel has been used traditionally as a drug for diabetes mellitus. The aim of this research was to know the effect of fruit peel ethanolic extract of jengkol (Archidendron pauciflorum) (JFPEE) on rat's (Rattus norvegicus) heart histological structure and to obtain an effective dose from JFPEE. This research used an experimental method in the laboratory with Completely Random Design (CRD) using 6 treatments and 4 replications. Treatment was given for 14 consecutive days consisting of negative control, positive control, comparison (glibenclamide dose $10 \mathrm{mg} / \mathrm{kg} \mathrm{BW}$ ), P1, P2, and P3 (JFPEE dose 385, 770, and $1.540 \mathrm{mg} / \mathrm{kg} \mathrm{BW}$ ). Diabetic induction was performed with a $65 \mathrm{mg} / \mathrm{kg}$ BW streptozotocin dose in female Wistar rats except for the negative control group. The observed parameters were several necroses and cell damage scores, including fat degeneration, hydropic degeneration, and inflammatory cell. The obtained data were analyzed by ANOVA-Tukey's test with a 95\% confidence level using SPSS version 21 for Windows. The result of the histological structure showed that several necroses and cell damage scores in a group of rats treated with a JFPEE dose of $385 \mathrm{mg} / \mathrm{kg} \mathrm{BW}(174.25 \pm 6.34 ; 1.25 \pm 0.50)$ were not significantly different from the negative control rats $(172.00 \pm 7.62 ; 1.00 \pm 0.00)$. The effective dose of JFPEE that can repair the damage to heart cell's rat induced by streptozotocin was $385 \mathrm{mg} / \mathrm{kg} \mathrm{BW}$.
\end{abstract}

Keywords: Archidendron pauciflorum, heart, jengkol fruit peel, rat, streptozotocin

\section{INTRODUCTION}

The total population of Diabetes Mellitus (DM) patients in Indonesia is estimated to reach 8.2 million patients over the age of 20 by 2020 . Indonesia is ranked 7 th out of 10 countries with the highest number of people with diabetes globally (IDF 2015). Diabetes Mellitus is a chronic metabolic disease disorder because the pancreas cannot produce enough insulin or the body cannot effectively use insulin production, resulting in an increase in glucose concentration in the blood or hyperglycemia (Kemenkes 2014).

DM can affect all organs of the body and cause various complaints, one of which is heart trouble, such as coronary heart disease (CHD), congestive heart failure, and stroke (Fatimah 2015). According to the American Heart Association, in May 2012, less than $65 \%$ of people with diabetes died of heart disease or stroke. In addition, adults who suffer from DM are two to four times more likely to develop heart disease than people without diabetes.

One of the organs that has the most important function is the heart. The heart serves as a pumping device to circulate blood, either to the lungs or all other organs of the human body, because of the importance of this heart function, so if there is a disturbance or damage to this organ will result in disruption of all system performance in the body of mammals (Anggraeni et al. 2017).
Streptozotocin (STZ) is a chemical compound in the form of broad-spectrum antibiotics. It is a toxic compound for pancreatic beta cells that produce the hormone insulin because it can destroy its cells. The induction of STZ as a diabetic agent is very convenient and easy to use (Abeeleh et al., 2009). STZ is an N-nitrosourea and D-glucosamine derivative structurally isolated from Streptomyces achromogenes (Raza and John 2013).

A chemical drug that people with diabetes mellitus often use is type glibenclamide. According to Mulyanti (2010), diabetes Mellitus requires serious handling. The adverse effects of synthetic drugs used to treat DM are the main reason for searching for natural antihyperglycemic drugs. Currently, traditional medicine is often used by the community for self-medication. Before modern medicine was discovered and marketed, traditional medicine in Indonesia had been going on for thousands of years. Traditional medicine is widely used to treat chronic diseases such as diabetes mellitus (Pramono 2002). One of the plants that have been used traditionally in some areas in Indonesia as a drug for diabetes mellitus is jengkol peel (Syafnir et al. 2014).

Based on the results of research Rahayu and Pukan (2008) disclosed that the content of chemical compounds in jengkol peel are alkaloid, steroid/triterpenoid, saponin, flavonoid, and tannin, and the jengkol fruit peel also contains protein, vitamin $\mathrm{A}$, vitamin $\mathrm{B}$, phosphorus, and 
calcium. Jengkol fruit peel is a good source of protein because it plays a role in the body's development and can repair damaged cells. Therefore, the peel of jengkol fruit (A. pauciflorum) is thought to have the potential to keep the heart organ healthy in people with diabetes, observed through damage to cells in the heart. In this research, the effect of ethanol extract of jengkol peel on histology of heart organ in rat/mouse (Rattus norvegicus) induced by streptozotocin was observed.

\section{MATERIALS AND METHODS}

\section{Material preparation and diabetes induction}

Production of ethanol extract of jengkol fruit peel was done by maceration method using ethanol $70 \%$. The obtained maceration was then filtered and then concentrated with a rotary evaporator at a temperature of $40{ }^{\circ} \mathrm{C}$ (Khan et al. 2012) to obtain an extract in the form of a paste.

The test animal was acclimatized in the Biology Department animal cage for seven days with a temperature of $22-30^{\circ} \mathrm{C}$. Test animals were given feed and drink with tap water by ad-libitum (IACUC 2015). Replacement of the chamber cage is done twice a week.

The test animal was checked for its glucose level and fasted for 12 hours. The test animals were then induced with streptozotocin dissolved in $0.1 \mathrm{M}$ citrate buffer $(\mathrm{pH}$ 4.5) with a single dose of $65 \mathrm{mg} / \mathrm{kg} \mathrm{BW}$ intravenously. After 72 hours of STZ induction, the blood glucose levels of test animals were examined. Rats used as test animals were rats possessing blood glucose $>250 \mathrm{mg} / \mathrm{dl}$ on day 3 of the test (72 hours after STZ induction) (Furman 2015).

Ethanol extract of jengkol fruit peel is given orally every day for 14 days in a row according to the dose of each treatment. The extract was administered on day 4 after STZ injection and was considered to be the $1^{\text {st }}$ day and lasted up to 14 days (Sajedianfard 2014).

\section{Histological incision preparation}

After administration the extract for 14 days, the rat dislocated the neck, dissected, and isolated the heart organ. The organ was washed with $0.9 \% \mathrm{NaCl}$ to remove blood residue and dried with filter paper. The histological incision of the cardiac organ is made by isolating the cardiac organ fixed in the Bouin solution for 24 hours. Then the heart organ was cut transversely and washed in alcohol $70 \%$ for 24 hours. Afterward, the organ was dehydrated in a series of alcohol and 100\% alcohol-based clarification: xylol. Then, the heart organ was infiltrated in xylol: paraffin and embedding in paraffin in the oven at 60$70^{\circ} \mathrm{C}$. Then the organ was cut using a microtome with a thickness of 5 microns at a temperature $<24^{\circ} \mathrm{C}$.

Staining was done using Hematoxylin-Eosin (HE). The stages performed in this staining began with deparaffinization. Then rehydration process in a series of alcohol, which was then put into Hematoxylin solution for 25 minutes, and the histological incision was washed with tap water flowing. The histological incision was then introduced into a solution of Eosin for 10 seconds and dehydrated in a series of alcohols. It was then purified in a solution of xylol series and dried at room temperature, and covered with a sliding glass cover.

\section{Histological sample observation}

Histological incision of heart dyed in HematoxylinEosin was then observed histological structure using a light microscope. The observation of necrosis was performed by looking at 1000 myocardial cells, which were then counted. Other changes were observed, such as infiltration of inflammatory cells, fat degeneration, and hydropic degeneration, were scored degrees of its severity using the method Karthikeyan et al. (2007), as follows: (0) no change; (1) mild (focal damage to myocytes or small multifocal degeneration with slight inflammatory processes); (2) moderate (broad myofibrillar degeneration and/or inflammatory of the difusa); (3) severe (widespread degeneration with inflammation of the difusa).

\section{Data analysis}

The histologic observation of rat heart (Rattus novergicus) Wistar was analyzed by One-Way ANOVA parametric statistic and continued with the Tukey test using SPSS for Windows version 21 (Sudjana 2012). In OneWay ANOVA, $\mathrm{H}_{0}$ is accepted when $\mathrm{F}_{\text {count }}<\mathrm{F}_{\text {table, and }} \mathrm{H}_{1}$ is accepted when $\mathrm{F}_{\text {count }}>\mathrm{F}_{\text {table }}$ at the real level $(\alpha=0.05)$. If $\mathrm{H}_{1}$ is accepted, the statistical test continues with the Tukey test.

\section{RESULTS AND DISCUSSION}

\section{Observation of cardiac histological structure}

Observations of cardiac histological structures include the total necrotic cell, fat degeneration illustrations, hydropic degeneration, and inflammatory cell infiltration. The histological cross-section of the heart organ of the post-treatment 14-day is presented in Figure 1. The positive control induced by streptozotocin showed necrotic cells, hydropic degeneration, and inflammatory cell infiltration. The negative control did not occur without streptozotocin induction, with only necrotic cells and hydropic cell degeneration. Fat degeneration was observed in the treatment of P1 and P3. The average number of normal cells and necrosis cells is presented in Table 1, whereas the illustrations of fat degeneration, hydropic degeneration, and inflammatory cell infiltration are presented in Table 2.

\section{Necrosis cell}

The result of the ANOVA test for necrotic cell count shows that $F_{\text {count }}(61,040)>F_{\text {table }}(2,77)$, which means that there is a significant difference in at least one treatment group showing that jengkol fruit peel extracts affected the histological structure of female Wistar rat ( $R$. novergicus) heart organ. This also means that the administration of jengkol fruit skin extract significantly affected the number of female Wistar rat ( $R$. novergicus) heart necrosis cells. The data analysis continued with the Tukey test to determine the most significant difference between all treatments. 


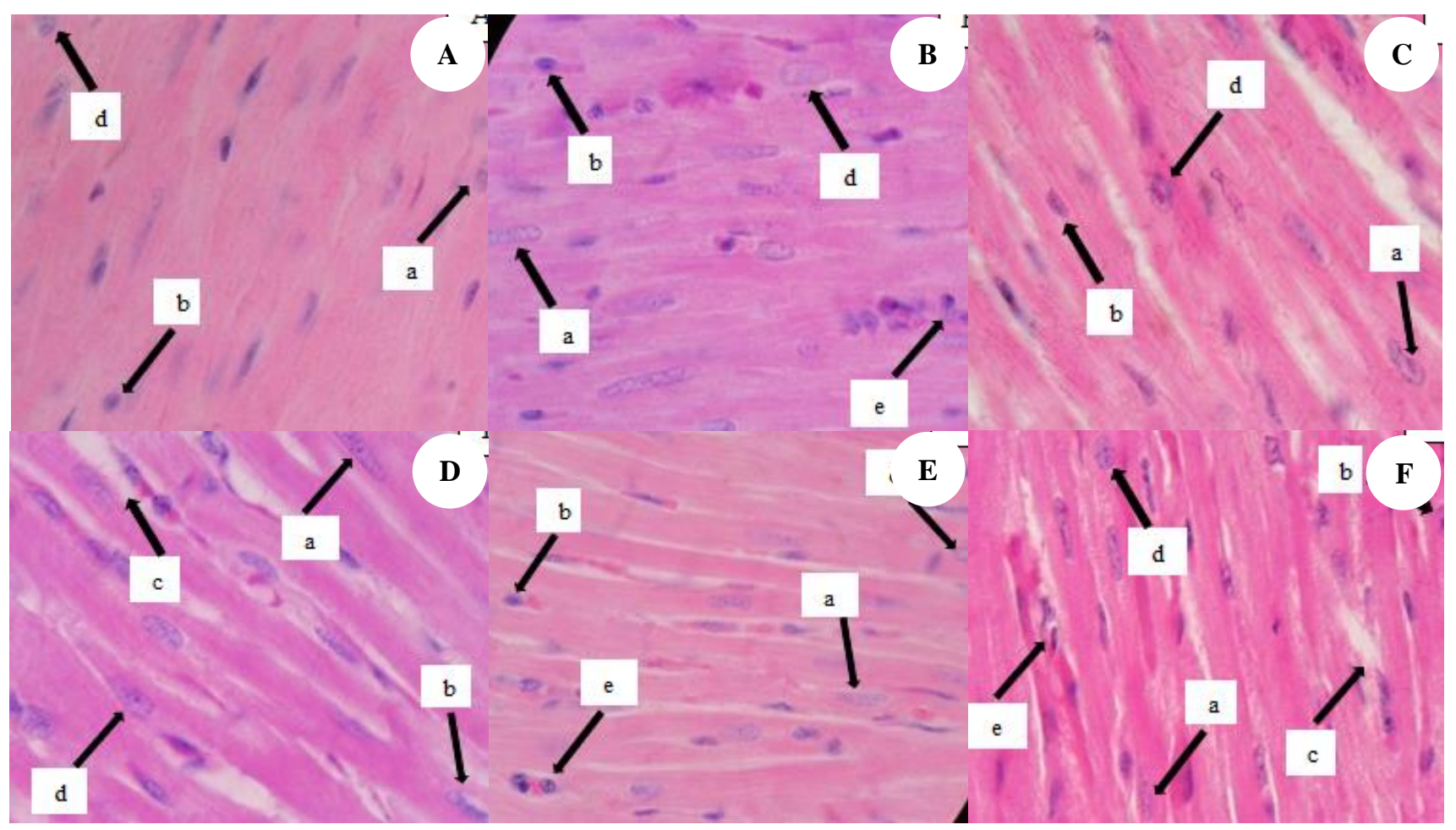

Figure 1. Histological cross section incision of rat heart. Note: (A) NC (CMC 0,5\%); (B) PC (STZ $65 \mathrm{mg} / \mathrm{kg} \mathrm{BW}+\mathrm{CMC} \mathrm{0,5 \% );} \mathrm{(C)} \mathrm{Pb}$ (STZ $65 \mathrm{mg} / \mathrm{kg} \mathrm{BW}+$ CMC 0,5\% + Glibenklamide $10 \mathrm{mg} / \mathrm{kg}$ BW); (D) P1 (STZ $65 \mathrm{mg} / \mathrm{kg}$ BW + CMC 0,5\% + Jengkol Fruit Peel Extract $385 \mathrm{mg} / \mathrm{kg} \mathrm{BW}$ ); (E) P2 (STZ $65 \mathrm{mg} / \mathrm{kg} \mathrm{BW}+$ CMC 0,5\% + Jengkol Fruit Peel Extract $770 \mathrm{mg} / \mathrm{kg} \mathrm{BW}$ ); (F) P3 (STZ 65 mg/kg BW + CMC 0,5\% + Jengkol Fruit Peel Extract $1.540 \mathrm{mg} / \mathrm{kg} \mathrm{BW}$ ). [a] normal cell; [b] necrosis cell; [c] fat degradation; [d] hydrophic degradation; dan [e] inflammatory cell inflammation

Table 1. The average number of necrosis cells in rat heart myocardium post-treatment

\begin{tabular}{lc}
\hline Treatment group & Average of necrosis cell \\
\hline Negative control & $172.00 \pm 7.62^{\mathrm{a}}$ \\
Positive control (STZ) & $234.50 \pm 6.56^{\mathrm{b}}$ \\
$\mathrm{Pb}(\mathrm{Glibenklamide})$ & $185.50 \pm 6.76^{\mathrm{c}}$ \\
$\mathrm{P} 1(385 \mathrm{mg} / \mathrm{kg} \mathrm{BW})$ & $174.25 \pm 6.34^{\mathrm{ad}}$ \\
$\mathrm{P} 2(770 \mathrm{mg} / \mathrm{kg} \mathrm{BW})$ & $184.25 \pm 6.18^{\mathrm{cd}}$ \\
$\mathrm{P} 3(1540 \mathrm{mg} / \mathrm{kg} \mathrm{BW})$ & $222.75 \pm 7.04^{\mathrm{e}}$ \\
\hline
\end{tabular}

Note: Data were analyzed using ANOVA and Tukey test with a $95 \%$ confidence level. Different letters in one column show a real difference $(\mathrm{p}<0.05)$.

Table 2. Average of scoring damage to mouse heart posttreatment myocardium

\begin{tabular}{lc}
\hline Treatment group & Average of scoring \\
\hline Negative control & $1.00 \pm 0.00^{\mathrm{a}}$ \\
Positive control (STZ) & $2.75 \pm 0.50^{\mathrm{c}}$ \\
$\mathrm{Pb}($ Glibenklamide $)$ & $1.25 \pm 0.50^{\mathrm{ab}}$ \\
$\mathrm{P} 1(385 \mathrm{mg} / \mathrm{kg} \mathrm{BW})$ & $1.25 \pm 0.50^{\mathrm{ab}}$ \\
$\mathrm{P} 2(770 \mathrm{mg} / \mathrm{kg} \mathrm{BW})$ & $1.00 \pm 0.00^{\mathrm{a}}$ \\
$\mathrm{P} 3(1540 \mathrm{mg} / \mathrm{kg} \mathrm{BW})$ & $2.00 \pm 0.00^{\mathrm{bc}}$ \\
\hline
\end{tabular}

Note: Data were analyzed using ANOVA and Tukey test with a 95\% confidence level. Different letters in one column show a real difference $(\mathrm{p}<0.05)$.
Results of cardiac histologic observations showed that streptozotocin-induced rats had higher numbers of necrotic cells $(234,50 \pm 6.56)$ than a streptozotocin-non-induced rats $(172.00 \pm 7.62)$. Normal cells in people with diabetes will experience a decrease in the amount caused by damage to cells. This is in accordance with the results of research conducted by Sari (2015) that the induction of streptozotocin causes heart organ permanent cell damage in the form of myocardium cell cytoplasm vacuolization.

Necrosis is the death of tissue cells due to injury when an individual is alive. Microscopically, the core changes are the loss of chromatin image, the core wrinkle, not vesicular anymore, the core appears denser, the color is dark black (pyknosis), the core is divided into fragments, torn (karyokinesis), and no longer to take much color because it is pale, not real (karyolysis) (Suhita et al. 2013).

Tukey test results showed that rats treated with jengkol fruit peel extract at each dose were significantly different from those given streptozotocin. This means that the administration of jengkol fruit peel extract can repair cell damage in the heart of diabetics by reducing the number of necrosis cells. In rats treated with jengkol fruit peel extract at a dose of $385 \mathrm{mg} / \mathrm{kg} \mathrm{BW}$, it does not differ significantly from the control group rats without streptozotocin-induced induction. This means that the extract of jengkol fruit peel at a dose of $385 \mathrm{mg} / \mathrm{kg}$ BW had a better effect on reducing the number of necrosis cells than the comparison 
(glibenclamide drug) effect was close to the normal condition of the streptozotocin-non induced rat. The rat treated with jengkol fruit peel extract at a dose of 385 $\mathrm{mg} / \mathrm{kg} \mathrm{BW}$ had fewer necrotic cells $(174.25 \pm 6.34)$ than

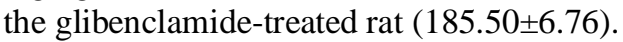

The peel of jengkol fruit contains tannin and flavonoids, which apparently prevent and repair cell damage by increasing the number of normal cells. Karodi et al. (2009) state that tannin performs wound healing activity by increasing the regeneration and organization of new tissues. In contrast, according to Harisaranraj et al. (2009), flavonoids are water-soluble antioxidants that clean up free radicals and prevent oxidative cell damage. They also have strong anti-cancer and anti-inflammatory activity. The results of microscopic histological observation show that the changes in rat heart happen due to the administration of streptozotocin, glibenclamide drug, or treatment given in three doses $(385 \mathrm{mg} / \mathrm{kg} \mathrm{BW}, 770 \mathrm{mg} / \mathrm{kg} \mathrm{BW}$, and 1540 $\mathrm{mg} / \mathrm{kg} \mathrm{BW}$ ), which could be observed from the degeneration of fat, degeneration of hydropic, and inflammatory cell infiltration.

Scoring Damaged CellThe result of the ANOVA test for cell damage score showed that $F_{\text {count }}(15,533)>F_{\text {table }}$ $(2,77)$, which means there is a significant difference in at least one group of treatments that showed that fruit jengkol skin extract affected the histological structure of female rat ( $R$. novergicus) Wistar heart. It also means that the administration of jengkol fruit peel extracts significantly affected the degree of mast cell damage in female rats $(R$. novergicus) Wistar heart. The data analysis was continued with the Tukey test to find out the most significant different treatments.

Tukey test results showed that mice treated with jengkol fruit peel extract at a dose of $385 \mathrm{mg} / \mathrm{kg} \mathrm{BW}$ and $770 \mathrm{mg} / \mathrm{kg}$ BW did not differ significantly from the negative control group that was not induced by streptozotocin (Table 2). This means that the jengkol fruit peel extract of doses of $385 \mathrm{mg} / \mathrm{kg} \mathrm{BW}$ and $770 \mathrm{mg} / \mathrm{kg} \mathrm{BW}$ had a better effect on the reduction of the cell damage caused by fat degeneration, hydropic degeneration, and inflammatory cell infiltration when they were compared with comparison (glibenclamide drug) so that their effects were near the normal condition of rats with no streptozotocin induction. In rats treated with jengkol fruit peel extract at a dose of $1540 \mathrm{mg} / \mathrm{kg}$ BW was not significantly different from that of the positive control group induced by streptozotocin. This shows the extract of ethanol skin jengkol dose $1540 \mathrm{mg} / \mathrm{kg}$ bb had not been able to repair the damage to heart cells in people with diabetes mellitus.

Based on the observation, jengkol fruit peel extract is known to reduce necrosis in the cell. Fat degeneration is a metabolic disorder of cells that will cause cell damage and initiate the occurrence of necrosis. According to Aisyah et al. (2014), the damage to heart cells is characterized by the presence of vacuoles that accumulate on the walls. The vacuoles are fatty deposits, which are known as foam cells. If sedentary, the foam cell hardens and may clog the blood vessels, known as atherosclerosis. Fat degeneration is abnormal fat deposits in cells between connective tissue or degenerative changes leading to cellular necrosis. This occurs in diabetes mellitus, malnutrition, ischemic, and severe anemia conditions.

\section{Discussion}

Fat degeneration is an abnormal fat accumulation in the cytoplasm, vacuoles, and urgent nuclei to the edges. Fat degeneration describes the abnormal accumulation of triglycerides in parenchymal cells. The etiology of fatty degeneration is a toxin, protein malnutrition, diabetes mellitus, obesity, and anoxia. The consequences of changes in fat depending on the amount of fat deposits. If there are not too many fat deposits, the cell function is not disrupted, but if there are excess fat deposits, it will cause changes in fatty cells and cause necrosis (Suhita et al. 2013).

Cell cytoplasm vacuolization is a feature of hydropic degeneration, which is the accumulation of further water in the cells due to mitochondrial damage, the cessation of ATP production, and the sodium pump's failure, causing an increase in osmotic pressure in the cell. Severe hydropic degeneration results in necrosis of the cells (Salim and Balqis 2017). Hydropic degeneration occurs when a vacuole containing water in a cytoplasm containing no fat or glycogen is present; the cytoplasm becomes pale and swollen with fluid retention. This change is generally a result of metabolic disorders such as hypoxia or chemical toxicity. This change is reversible, although it can also be irreversible if the cause of the injury persists. If a rupture of the plasma membrane occurs and changes in the nucleus, the cell becomes irreversible and dies (Kasno 2005).

Hydrophic degeneration is characterized by cellular swelling, the presence of empty spaces (vacuoles), enlarged and docked cells. Hydropic degeneration is a reversible cell lesion with more severe intracellular accumulation when it is accompanied by albumin. Its etiology is similar to cell swelling, only the intensity of pathological stimuli is more severe, and the duration of exposure to pathologic stimulation is longer. Hydropic degeneration is common in epithelial cells (Suhita et al., 2013).

According to Braun and Anderson (2010), dead cells are chemically altered, and adjacent living tissues respond to the change and cause an inflammatory reaction. Cell inflammation is a vascular reaction that results in the delivery of fluids, dissolved substances, and cells from the blood circulation to the interstitial tissues of the necrosis region.

Inflammation or an inflammatory reaction is an important mechanism that the body needs to defend itself from various dangers that disrupt the balance and improve the structure and disruption of tissue function caused by the hazard. Inflammation is characterized by plasma protein fluid transfer and leukocytes from the blood circulation into the tissues in response to hazards. Inflammation can be characterized by redness, heat, swelling, pain, and disruption of body functions. Histopathologically, inflammation is characterized by the infiltration of inflammatory cells (Baratawidjaja 2002).

The results showed that the treatment using jengkol fruit peel extract (A. pauciflorum) could affect normal cell count, necrosis cell count, fat degeneration, hydropic 
degeneration, and inflammation of inflammatory cells almost the same with a negative control without streptozotocin induction. Fruit ethanol extract of jengkol fruit has a good effect on each parameter at a dose of 770 $\mathrm{mg} / \mathrm{kg} \mathrm{BW}$, increasing normal cell count, decreasing cell necrosis, repairing cell damage based on fat degeneration, hydropic degeneration, and inflammatory cell infiltration. This suggests that jengkol fruit peel extract (A. pauciflorum) has the potential to improve the histologic damage of rat ( $R$. novergicus) heart induced by streptozotocin.

Biochemical compounds in the peel extract of jengkol fruit (A. pauciflorum) include tannins, flavonoids, alkaloids, quinones, steroids/triterpenoids, saponins, and polyphenols can reduce cellular necrosis and increase regeneration of new tissues in cardiac myocardium. These compounds also act as antioxidants that help repair tissue damage to the heart. Jengkol fruit peel also contains protein, vitamin A, B vitamins, phosphorus, and calcium that play a role in the body's development and can repair back damaged cells.

Based on the results of this study, it can be concluded that the provision of jengkol fruit peel extract ( $A$. pauciflorum) can improve the damage to the histological structure of the heart, which could be observed from the number of necrosis cells and score damage picture caused by fat degeneration, hydropic degeneration, and inflammatory cell inflammation on Wistar rat $(R$. norvegicus) induced by streptozotocin. The dose of ethanol extract from the jengkol fruit peel (A. pauciflorum) effectively repairs cell damage in female rats $(R$. norvegicus). Wistar heart induced by streptozotocin was $385 \mathrm{mg} / \mathrm{kg} \mathrm{BW}$. However, a toxicity test of ethanol extract of jengkol fruit peel for 28 days is required to know the toxic level of jengkol fruit peel to other body organs to prevent other negative effects inflicted on people with diabetes mellitus. In addition, further research on the effect of the duration of jengkol fruit peel extract on the histological and morphological structure of Wistar female rats is required. The optimum duration of time in the extract of jengkol fruit required peel can be obtained.

\section{REFERENCES}

Abeeleh MA. 2009. Induction of diabetes mellitus in rats using intraperitoneal streptozotocin: a comparison between 2 strains of rats. Eur J Sci Res 32 (3): 398-402.

Braun CA, Anderson CM. 2010. Pathophysiology: A Clinical Approach 2nd ed. Lippincott Williams \& Wilkins, Philadelphia, PN

Aisyah S, Balqis U, Friyan EK. 2014. Histopatologi jantung tikus putih (Rattus novergicus) akibat pemberian minyak jelantah. Jurnal Medika Veterinaria 8 (1): 87-90. [Indonesian]

AHA [American Heart Association]. 2012. Cardiovascular Disease and Diabetes. American Heart Association, Washington DC.
Anggraeni IDAR, Bodhi W, Simbala H. 2017. Pengaruh ekstrak etanol buah pinang yaki (Areca vestiaria) terhadap gambaran makroskopis organ jantung pada tikus putih jantan galur wistar (Rattus novergicus). Pharmacon Jurnal Ilmiah Farmasi 6 (3): 65-73. [Indonesian]

Aniagu SO, Binda LG, Nwinyi FC, Orisadipe A. 2005. Anti-diarrhoeal and ulcer-protective effects of the aqueous root extract of Gueira senegalensis in rodents. J Ethnopharmacol 97: 549-554.

Baratawidjaja KG. 2002. Imunologi Dasar. Edisi 5. Balai Penerbit Fakultas Kedokteran Universitas Indonesia. Jakarta. [Indonesian]

Fatimah RN. 2015. Diabetes mellitus tipe 2. J Majority 4 (5). [Indonesian]

Furman BL. 2015. Streptozotocin-induced diabetic models in mice and rats. Curr Protoc Pharmacol 70: 5.47.1-5.47.20.

Harisaranraj R, Suresh K, Saravanababu S. 2009. Evaluation of the chemical composition Rauwolfia serpentina and Ephedra vulgaris. Adv Biol Res 3 (5): 174-178.

IACUC. 2015. Standard Operating Procedure: Food Restriction in Rodents. University of Connecticut, Storrs, CT, USA.

IDF. 2015. International Diabetes Federation. www.idf.org (accessed on 13 October 2017)

Karodi R, Jadhav M, Rub R, Bafna A. 2009. Evaluation of the wound healing activity of a crude extract of Rubia cordifolia L. (Indian madder) in mice. Intl J Appl Res 2 (2): 12-18.

Karthikeyan K, Sarala Bai BR, Niranjali Devaraj S. 2007. Cardioprotective effect of grape seed proanthocyanidins on isoproterenol-induced myocardial injury in rats. Intl J Cardiol 115: 326-333.

Kasno PA. 2005. Patologi Hati dan Saluran Empedu Ekstra Hepatik. Balai Penerbit Universitas Diponegoro, Semarang. [Indonesian]

Kemenkes. 2015. InfoDATIN: Waspada Diabetes, Situasi, dan Analisis Diabetes. Pusat Data dan Informasi Kementerian Kesehatan RI. http://www.depkes.go.id (Accessed on 13 October 2017). [Indonesian]

Khan J, Yadav Y, Srivastava Y, Pal PK. 2012. In vitro evaluation of antimicrobial properties of Carica papaya. Intl J Biol Pharma Allied Sci 1 (7): 933-945.

Mulyanti. 2010. Keperawatan Keluarga. CV. Trans Info Media. Jakarta. [Indonesian]

Pramono E. 2002. The commercial use of traditional knowledge and medicinal plants in Indonesia. Submitted for multi-stakeholder dialoque on trade, intellectual property and biological resources in Asia. BRAC Centre for Development Management: April 19-21, Rajendrapur, Bangladesh.

Rahayu ES, Pukan KK. 2008. Kandungan Senyawa Alelokemi Kulit Buah Jengkol dan Pengaruhnya terhadap Beberapa Gulma Padi. [Karya Ilmiah]. FMIPA IKIP Semarang. [Indonesian]

Raza H, John A. 2013. Streptozotocin-induced cytotoxicity, oxidative stress and mithocondrial dysfunction in human hepatoma hepG3 cells. Intl J. Mol. Sci 1 (13): 5751-5767.

Sajedianfard J, Nazifi S, Shamsaei HA. 2014. The effects of oral administration of different doses of hydroalcoholic extract of silymarin on status of serum trace elements. Amer J Anim Vet Sci. 9 (3): 170-176.

Salim N, Balqis U. 2017. Pengaruh ekstrak daun jamblang (Syzygium cumini L.) terhadap histopatologi hepar tikus putih (Rattus novergicus) diabetes mellitus. Jurnal Ilmiah Mahasiswa Veteriner 1 (4): 695-701.

Sari LP. 2015. Histopatologis Pankreas, Jantung, Ginjal, dan Hati Tikus (Rattus novergicus) yang Diinduksi Streptozotocin. [Hon. Thesis]. Fakultas Kedokteran Hewan Universitas Gadjah Mada, Yogyakarta. [Indonesian]

Sudjana. 2012. Metode Statistika. Tarsito, Bandung. [Indonesian]

Suhita NLPR, Sudira IW, Winaya IBO. 2013. Histopatologi ginjal tikus putih akibat pemberian ekstrak pegagan (Centella asiatica) peroral. Buletin Veteriner Udayana 5 (2): 71-78. [Indonesian]

Syafnir L, Krishnamurti Y, Ilma M. 2014. Uji aktivitas antidiabetes ekstrak etanol kulit jengkol (Archidendron pauciflorum (Benth.) I.C. Nielsen). Prosiding SNaPP2014 Sains, Teknologi, dan Kesehatan 4 (1): 65-72. [Indonesian] 